\title{
STRATEGI KOMUNIKASI DIVISI PUBLIC RELATIONS PLN DISTRIBUSI JAWA BARAT DALAM SOSIALISASI SUBSIDI LISTRIK TEPAT SASARAN
}

\author{
Lyza Audina Pangesti, \\ Mahasiswa Program Studi Ilmu Komunikasi Universitas Telkom \\ lyzaaudina19@gmail.com
}

\begin{abstract}
ABSTRAK
Skripsi ini membahas mengenai strategi komunikasi yang dilakukan oleh PLN Distribusi Jawa Barat dalam sosialisasi program subsidi listrik tepat sasaran. Program subsidi listrik tepat sasaran ini merupakan program yang diturunkan oleh pemerintah mengenai pencabutan subsidi kepada pelanggan 900 VA yang mampu, dimana provinsi Jawa Barat menduduki peringkat paling tinggi se Indonesia. Penelitian ini bertujuan untuk mengetahui bagaimana tahap-tahap strategi komunikasi public relations PLN Distribusi Jawa Barat dalam melakukan sosialisasi program subsidi listrik tepat sasaran di Jawa Barat. Penelitian ini menggunakan paradigma konstruktivis, pendekatan kualitatif dan strategi penelitian studi kasus. Metode pengumpulan data dalam penelitian ini adalah wawancara mendalam dan studi dokumen. Hasil penelitian menunjukkan bahwa public relations PLN pusat menjadi salah satu tim komunikasi yang merencanakan dan memberikan instruksi kepada PLN Unit dibawahnya yaitu public relations PLN Distribusi Jawa Barat dalam melakukan sosialisasi program subsidi listrik tepat sasaran. Tahap-tahap startegi komunikasi yang dilakukan public relations PLN Distribusi Jawa Barat dalam sosialisasi subsidi listrik tepat sasaran adalah dengan menentukan tim komunikasi, mengenali khalayak, menyusun pesan, menetapkan metode dan terakhir seleksi dan penggunaan media.
\end{abstract}

Kata kunci: Strategi Komunikasi, Public Relations, PT. PLN

\begin{abstract}
This thesis discuss about the communication strategy which have been implemented by public relations of PLN due to socializing well-targeted electricity subsidy program in West Java. This Well-targeted electricity subsidy program is a government program which cuts the electricity subsidy for middle income homes 900-watt customer, where West Java province is ranked the highest in Indonesia. The goal of this research is to know the steps of communication strategy which have been implemented by public relations PLN West Java Distribution due to socializing well-targeted electricity subsidy program. This research uses constructivist paradigm, qualitative approach and case-study research strategy. The data were collected by in depth interview and documentation study. The result revealed that the public relations of PLN becomes one of the communicator who planned and give the instructions to public relations of PLN West Java Distribution in socializing well-targeted electricity subsidy program. The communication strategy steps which have been implemented by public relations of PLN due to socializing well-targeted electricity subsidy program are determined the communicator, recognizes the audiences, set the method and last selection and media uses.
\end{abstract}

Key words: Communication Strategy, Public Relations, PT PLN 


\section{PENDAHULUAN}

Setiap organisasi pasti memiliki public relations sebagai jembatan dalam hubungan internal maupun eksternal organisasi. Nurjaman \& Umam (2012:147) menyatakan bahwa bidang public relations merupakan salah satu aspek manajemen yang diperlukan oleh setiap organisasi, baik organisasi yang bersifat komersial (perusahaan) maupun organisasi yang nonkomersial. Bagi perusahaan milik negara atau lebih dikenal dengan BUMN, kelangsungan perusahaan tersebut ditentukan pula oleh pemerintah. Perusahaan Listrik Negara (PLN) merupakan satu-satunya perusahaan milik negara di sektor listrik dan memastikan bahwa setiap orang diseluruh Indonesia memiliki akses terhadap listrik. Kebutuhan akan listrik merupakan kebutuhan yang primer, dimana menjadi kebutuhan utama masyarakat dalam menjalankan aktivitasnya sehari-hari. Pada tanggal 22 September 2016 telah dikeluarkan peraturan Menteri Energi dan Sumber Daya Mineral Nomor 28 Tahun 2016 tentang Tarif Tenaga Listrik yang disediakan oleh PT PLN (Persero), bahwa terhadap rumah tangga mampu 900 VA, mulai 1 Januari 2017 tarifnya disesuaikan menuju tarif keekonomian secara bertahap setiap dua bulan, sedangkan rumah tangga miskin dan tidak mampu 900 VA tarifnya tetap dan diberikan subsidi listrik (sumber : jdih.esdm.go.id). Menteri Energi dan Sumber Daya Mineral menilai bahwa pencabutan subsidi tersebut dikarenakan banyak masyarakat yang tergolong mampu tapi tetap mendapatkan subsidi. Pemerintah mengalihkan anggaran subsidi tersebut untuk hal-hal yang lebih prioritas, seperti mengalokasikannya untuk pembangunan pembangkit dan jaringan transmisi. Pencabutan subsidi 900 VA ini merata di seluruh wilayah Indonesia. Sebanyak 3,8 Juta pelanggan listrik 900 VA di provinsi Jawa Barat mengalami pencabutan subdisi listrik yang merupakan terbanyak di Indonesia. Melihat respon dari masyarakat yang mengalami pencabutan subsidi, selama kurun waktu awal tahun 2017 PLN telah melakukan berbagai macam upaya untuk menghadapi pencabutan subsidi dan menyosialisasikan program tersebut. Upaya ini merupakan bentuk komunikasi dari PLN kepada masyarakat, dimana tentu sebelum dilakukannya komunikasi, PLN terlebih dahulu melakukan strategi komunikasi. Strategi komunikasi merupakan keseluruhan perencanaan, taktik dan cara yang akan dipergunakan untuk melancarkan komunikasi dengan memerhatikan keseluruhan aspek yang ada pada proses komunikasi untuk mencapai tujuan yang diinginkan (Abidin, 2015:115). Proses yang selama ini dilakukan oleh pihak PLN adalah dengan membina hubungan baik dengan masyarakat dan mendapatkan kesepahaman mengenai pencabutan subsidi dan program Subsidi Listrik Tepat Sasaran. Salah satu upaya yang dilakukan PLN, khususnya Distribusi Jawa Barat adalah memberikan informasi melalui media sosial. PLN mengunggah beberapa informasi yaitu mengenai penyesuaian tarif tenaga listrik bulan Juli sampai dengan September 2017dan memberikan sosialisasi mengenai urgensi adanya subsiditepatsasaraniniagar masyarakat dapat memiliki kepahaman mengenai program 
tersebut agar terciptanya hubungan yang baik dengan pelanggan dan masyarakat. Hal ini merupakan tanggung jawab dari public relations suatu perusahaan. Dengan adanya upaya-upaya yang dilakukan oleh PLN, peneliti ingin mengetahui bagaimana tahaptahap strategi komunikasi yang dilakukan oleh public relations PLN Distribusi Jawa Barat dalam melakukan sosialisasi program subsidi listrik tepat sasaran.

\section{TINJAUAN PUSTAKA}

\section{Komunikasi}

Sebuah definisi yang dibuat oleh kelompok sarjana komunikasi yang mengkhususkan diri pada studi komunikasi antarmanusia (human communication) menjelaskan bahwa komunikasi adalah suatu transaksi, proses simbolik yang menghendaki orang-orang mengatur lingkungannya dengan (1) membangun hubungan antarsesama manusia; (2) melalui pertukaran informasi; (3) untuk menguatkan sikap dan tingkah laku orang lain; serta (4) berusaha mengubah sikap dan tingkah laku itu. (Book, 1980) dalam Cangara (2014:21).

Onong Effendy (2009:8) berpendapat bahwa fungsi komunikasi adalah (1) menyampaikan informasi (to inform), (2) Mendidik (to educate), (3) Menghibur (to entertain) dan Memengaruhi (to influence).

\section{Strategi Komunikasi}

Middleton (1980), seorang pakar perencanaan komunikasi memeberikan definisi strategi komunikasi yaitu kombinasi yang terbaik dari semua elemen komunikasi mulai dari komunikator, pesan, saluran (media), penerima sampai pada pengaruh (efek) yang dirancang untuk mencapai tujuan komunikasi yang optimal.

Strategi komunikasi harus didukung oleh teori karena teori merupakan pengetahuan berdasarkan pengalaman yang sudah diuji kebenarannya. Dalam Tatang (2016:84) teori strategi komunikasi yang memadai dikemukakan oleh Laswell, yaitu cara terbaik untuk menerangkan kegiatan komunikasi adalah menjawab pertanyaan, "Who Says What in Which Channel to Whom with What Effect?"

Fajar (2009:184) menjelaskan bahwa perumusan strategi dalam proses komunikasi semakin jelas diperlukan termasuk dalam Public Relations, yaitu: (1) mengenali khalayak, (2) menyusun pesan, (3) menetapkan metode, (4) seleksi dan penggunaan media.

Strategi komunikasi merupakan awal dari kegiatan komunikasi yang selalu terjadi dalam kehidupan sehari-hari, baik dalam lingkup komunikasi antar personal, komunikasi kelompok, maupun dalam komunikasi massa. Demikian juga dalam kehidupan organisasi, pasti akan diwarnai dengan aktivitas public relations, baik langsung maupun tidak langsung, sebab public relations adalah salah satu metode komunikasi. (Suryanto, 2015: 437)

\section{Public Relations}

Definisi public relations yang kemudian juga menghubungkan public relations sebagai manajemen adalah Denny Griswold, 
uitveger van Public Relations News, New York, dimana public relations merupakan fungsi manajemen yang mengevaluasi perilaku publik, mengidentifikasi kebijakan dan prosedur organisasi dengan perhatian ke publik dan melaksanakan program tindakan (komunikasi) untuk mendapatkan pemahaman dan pengertian publik.

Sebagai fungsi manajemen, public relations bertanggung jawab mengelola dan mengembangkan reputasi perusahaan. Sebagai fungsi komunikasi, public relations mengembangkan komunikasi antara perusahaan dan publik yang dianggap penting untuk menciptakan dan mempertahankan goodwill dan mutual understanding publik terhadap tujuan, kebijakan dan kegiatan perusahaan. Idealnya public relations adalah perpaduan dari kedua fungsi tersebut. Public relations yang efektif merupakan bagian mendasar bagi suatu perusahaan, bukan sekadar alat manajemen yang dapat ditiadakan atau dipindahkan. (Firsan Nova, 2011: 47)

\section{Sosialisasi}

Sosialisasi menurut Sobur (2014:734) adalah proses dimana masyarakat mendidik individu-individu bagaimana cara berperilaku, aturan apa yang harus dipatuhi, peranan yang harus dijalankan dan nilai yang harus diyakini.

\section{METODE PENELITIAN}

Penelitian ini menggunakan paradigma konstruktivistik karena penelitian ini bertujuan untuk menjabarkan dan menggambarkan realitas sosial, yaitu strategi komunikasi yang dilakukan public relations PLN dalam mensosialisasikan program subsidi listrik tepat sasaran di Jawa Barat

Pendekatan penelitian yang digunakan oleh penulis adalah pendekatan kualitatif, memiliki dua tujuan utama yaitu menggambarkan dan mengungkapkan (to describe and explore) dan tujuan yang kedua yaitu menggambarkan dan menjelaskan (to describe and explain), dimana bertujuan untuk memahami fenomena-fenomena sosial dari sudut pandang atau perspektif subyek/partisipan (Pujileksono, 2015:36). Sedangkan, metode penelitian yang digunakan dalam penelitian ini adalah studi kasus, karena ingin mendapatkan bagaimana proses dan pemahaman terkait sosialisasi program subsidi listrik tepat sasaran melalui strategi komunikasi. Pengumpulan data penelitian dilakukan dengan pengumpulan data primer, yaitu wawancara mandalam dengan informan kemudian data sekunder, yang merupakan studi dokumentasi. Teknik keabsahan data yang digunakan adalah triangulasi sumber, dimana mengecek data melalui beberapa sumber kemudian menggunakan bahan referensi.

\section{HASIL PENELITIAN DAN PEMBAHASAN}

\section{Hasil Penelitian}

Wawancara dilakukan dengan dua informan yaitu informan 1 adalah Santika Aristi, Assistant Analyst Public Relations PLN Pusat yang ikut serta merencanakan strategi komunikasi untuk sosialisasi program subsidi listrik tepat sasaran. Kemudian informan 2 
yaitu Octoyura Ridha Bamahry, Supervisor Humas dan Protokol PLN Distribusi Jawa Barat dimana bertugas dalam mengontrol kegiatan kehumasan dan protokoler di wilayah Jawa Barat.

\section{a. Mengenali Khalayak}

Informan 1 menjelaskan bahwa dalam merencanakan strategi komunikasi ini, PLN bekerjasama dengan beberapa lembaga yaitu DJK, TNP2K, Kemendagri dan Kementrian ESDM. Mengenali khalayak ini pun telah melalui tahap riset dalam menentukan khalayak atau sasaran komunikasi tersebut. Tahap riset mengenali khalayak pun tidak dilakukan oleh PLN Distribusi Jawa Barat, melainkan dilakukan langsung oleh PLN pusat yang bekerja sama dengan lembaga lainnya yaitu kementrian ESDM dan TNP2K. Khalayak dalam sosialisasi subsidi listrik tepat sasaran ini adalah pejabat pemerintah daerah, masyarakat yang mampu, media massa, opinion leader, masyarakat umum, pegawai PLN.

\section{b. Menyusun Pesan}

Peran PLN dalam program subsidi listrik tepat sasaran ini sebagai pelaksana, dimana pesan yang disampaikan lebih kepada edukasi kepada khalayak mengenai hemat listrik, manfaat $1 \mathrm{kwh}$, penggunaan listrik, perkembangan subsidi listrik dan hal-hal yang berkaitan lainnya. Bentuk pesan tersebut dipilih berdasarkan kepentingan bahwa adanya tujuan yang diinginkan oleh PLN terhadap masyarakat bahwa masyarakat dapat memiliki kesa- maan pemahaman mengenai subsidi listrik tepat sasaran. Selain edukatif, informan 2 juga menjelaskan bahwa pesan mengandung sifat informatif dan persuasive. Informatif lebih kepada secara tidak langsung memberikan informasi mengenai peraturan baru, sedangkan persuasif lebih kepada meyakinkan khalayak mengenai kepahaman program subsidi listrik tepat sasaran ini.

\section{c. Menetapkan Metode}

Penetapan metode dalam sosialisasi program subsidi tepat sasaran menurut informan 1, bahwa metode sosialisasi semuanya di instruksikan oleh PLN pusat, sehingga semua unit secara sama mendapatkan instruksi secara detail dan PLN Distribusi Jawa Barat hanya mencetak dan mengikuti instruksi dari PLN pusat tersebut, namun menurut informan 2 bahwa PLN Distribusi Jawa Barat juga merancang kembali instruksi tersebut. Selain itu, dalam melaksanakan sosialisasi ini informan 2 menyatakan bahwa sosialisasi paling penting dilakukan di awal saat memang program tersebut pertama dijalankan, sedangkan informan 1 mengatakan bahwa sosialisasi dilakukan secara berulang-ulang tidak hanya di awal saja. Media, opinion leader pun diberikan sosialisasi secara berulangulang, ditambahkan oleh sosialisasi dari unit PLN, termasuk PLN Distribusi Jawa Barat yang memang diberi instruksi dari PLN pusat untuk melakukan sosialisasi tersebut. 


\section{d. Seleksi dan Penggunaan Media}

Pemilihan media yang dilakukan oleh PLN dalam menyesuaikan khayalak dengan pesan dan metode yang telat ditetapkan adalah hanya dengan melihat media yang telah melakukan kerjasama sebelumnya, selanjutnya melihat kesesuaian dengan tujuannya. Jenis media apa saja yang dipilih untuk sosialisasi subsidi listrik tepat sasaran ini menurut informan 1, mereka menggunakan media cetak yaitu koran, poster, flyer dan buku, media elektronik yaitu televisi nasional dan radio serta media online yaitu melalui print ad dan media sosial seperti Facebook, Twitter, Instagram dan Youtube. Informan 2 menyatakan bahwa pemilihan media dilakukan awalnya dengan mengumpulkan redaktur dari media, kemudian mencari media cetak, elektronik maupun langsung ke rumah-rumah. Informan 1 kemudian menjelaskan secara garis besar mengenai proses pemilihan media yang juga melihat jangkauan dari media itu sendiri seperti apa, menyesuaikan dengan khalayak atau sasaran komunikasi sehingga akan lebih mudah terpapar. Sedangkan, menurut informan 2 penilaian dari jangkauan media yang dipilih untuk sosialisasi subsidi listrik tepat sasaran dinilai dari bagaimana pesan dapat sampai secara menyeluruh kepada khayalak, melalui berbagai macam media yang diharapkan dapat menyebarkan pesan tersebut.

\section{PEMBAHASAN}

\section{a. Mengenali Khalayak}

Sebelum pada tahap mengenali khalayak, tahap strategi komunikasi dalam sosialisasi program subsidi listrik tepat sasaran ini terlebih dahulu ternyata menentukan komunikator. Hal ini ternyata sesuai dengan teori strategi komunikasi yang dikemukakan oleh Laswell, bahwa dalam tahap pertama yaitu who (komunikator). Setiap aspek dari khalayak dalam sosialisasi subsidi listrik tepat sasaran memiliki kepentingan yang ikut menentukan kelancaran program subsidi listrik tepat sasaran. Hal ini sesuai dengan teori menurut Fajar (2009:184) bahwa komunikator harus mengerti dan memahami kerangka pengalaman dan kerangka referensi khalayak secara tepat dan seksama untuk mencapai kesamaan kepentingan. Public relations PLN juga melakukan pengenalan khalayak sesuai dengan tahap selanjutnya menurut Cangara (2013: 184), yaitu melihat kemampuan khalayak untuk menerima pesan lewat media-media dengan membedakan metode dan media apa yang diterapkan untuk menyampaikan sosialisasi, sehingga dipertimbangkan keefektifannya dalam menerima pesan dan selanjutnya yaitu melihat kemampuan khalayak dalam perbendaharaan katakata yang digunakan, dimana kata-kata dalam pesan pun disesuaikan agar tepat untuk setiap khalayak. Tidak ada riset yang secara khusus dilakukan oleh PLN Distribusi Jawa Barat, seperti tidak ada 
melihat norma dan nilai dari masyarakat atau suatu kelompok maupun situasi masyarakat itu berada, hal yang dilakukan per daerah hanya dalam segi pemadanan data saja.

\section{b. Menyusun Pesan}

Cangara (2013:116) menyatakan bahwa teknik penyampaian pesan dapat bersifat informative, persuasif dan edukatif. Ketiga sifat tersebut sudah terkandung dalam pesan yang disusun oleh public relations PLN dalam sosialisasi subsidi listrik tepat sasaran ini. Pesan sosialisasi juga mengandung two-sided issue, dalam teknik penyusunan pesan menurut Cangara (2013:115) karena isi pesan mengandung hal-hal kurang baik yang harus diperhatian dan juga hal-hal baik yang dapat diambil. Hal-hal kurang baik atau negatif yang terdapat dalam pesan sosialisasi ini adalah pesan urgensi subsidi listrik tepat sasaran, dimana secara tersirat pesan memberitahukan mengenai dampak negatif yang akan muncul apabila tidak dijalankannya program tersebut. Dari sisi hal-hal baik yang akan disampaikan, pesan dikemas dengan memberitahukan bahwa banyak hal-hal positif yang dapat diambil dari adanya program subsidi listrik tepat sasaran, sehingga khalayak dapat menilai dari dua sisi.

\section{c. Menetapkan Metode}

Sesuai dengan tahap menetapkan metode, yaitu redudancy atau cara mempengaruhi khalayak dengan mengulang- ulang pesan, public relations PLN telah mengikuti tahap tersebut. Pengulangan pesan diberikan kepada khalayak dipertimbangkan dengan melihat tone berita melalui vendor Isentia, sehingga dapat dianalisis berita yang negatif berasal dari media apa dan siapa narasumbernya, sehingga hal ini dapat lebih efektif untuk melihat bagian mana yang masih harus diberikan sosialisasi atau pengulangan pesan sehingga mengurangi adanya tone berita yang negatif. Namun hal ini berbeda dengan yang dijelaskan oleh PLN Distribusi Jawa Barat bahwa sosialisasi memang dilakukan hanya di awal saja untuk pemahaman di awal dan mengurangi dampak negatif berupa keluhan dari masyarakat, sehingga adanya perbedaan informasi dari PLN Pusat dan PLN Distribusi Jawa Barat. Penulis menganalisis bahwa PLN Distribusi Jawa Barat hanya sebagai pendistribusian informasi kepada PLN rayon yang lebih spesifik ke daerah tertentu, sehingga yang melakukan sosialisasi secara berulangulang merupakan PLN Rayon yang memang lebih dekat dengan masyarakat. Metode canalizing juga diterapkan oleh public relations PLN, sesuai dengan tahap-tahap strategi komunikasi dari Fajar (2009), yaitu mengenali khalayak, menyusun pesan kemudian menetapkan metode apa yang paling cocok untuk diterapkan setelah melihat dari tahap mengenali khalayak yang memang melihat kerangka referensi dan pengalamannya. Sehingga dapat dinilai bahwa public 
relations PLN menerapkan metode yang paling cocok disesuaikan dengan khalayaknya itu sendiri.

\section{d. Seleksi dan Penggunaan Media}

Tahap ini dilakukan sesuai dengan petunjuk pemilihan media yang dikemukakan oleh UNESCO, dimana tahap pertama melihat sumber daya komunikasi yang tersedia di suatu tempat. PLN Distribusi Jawa Barat menggunakan radio Mara FM sebagai coordinator untuk penyebaran sosialisasi melalui radio, dan media cetak koran yang telah melakukan kerjasama dengan PLN Distribusi Jawa Barat. Sehingga memang sudah bekerjasama dengan PLN sebelumnya, baik itu di pusat maupun di unit distribusi Jawa Barat, kemudian melihat apakah media tersebut cocok dengan khalayak. Tidak ada riset media dan analisis status sumber daya komunikasi yang dilakukan untuk menyasar khalayak secara khusus. Media yang digunakan juga melihat dari sisi one way communication dan two ways communication, dimana apabila one way communication dapat diberikan secara luas melalui media cetak, elektronik, online dan media sosial yang memang merupakan media massa yang hanya bersifat satu arah, meskipun memfasilitasi untuk adanya komunikasi yang interaktif, dimana memang dinilai dapat disebarluaskan secara cepat. Apabila two ways communication yang digunakan adalah secara langsung, seperti menyebarkan flyer dan brosur ke rumah warga, atau melalui kecamatan kelurahan yang memang mampu secara interaktif untuk menjawab apabila ada pertanyaan dari masyarakat.

\section{KESIMPULAN}

Tahap strategi komunikasi public relations PLN Distribusi Jawa Barat dalam sosialisasi program subsidi listrik tepat sasaran yaitu tahap pertama adalah menentukan tim komunikasi yang terdiri dari Kementrian ESDM, DJK, TNP2K, Kemendagri dan PLN. Tahap kedua adalah mengenali khalayak, yaitu Pejabat Pemerintah Daerah, masyakarat mampu, media massa, opinion leader, masyarakat umum dan pegawai PLN dengan memahami kondisi kepribadian dan kondisi fisik khalayak secara umum dikarenakan program ini sifatnya nasional sehingga sama untuk seluruh Indonesia. Tahap ketiga adalah menyusun pesan, dimana pesan mengandung sifat informatif, persuasif dan edukatif, serta two-sided issue. Selanjutnya tahap keempat adalah menetapkan metode, public relations PLN menetapkan metode redudancy, metode canalizing dan menggunakan vendor Isentia untuk menentukan tone berita terkait program susbidi listrik tepat sasaran, sehingga secara tepat menyasar kepada media dan khalayak mana yang perlu mendapat sosialisasi kembali. Tahap kelima, yaitu seleksi dan penggunaan media, dimana melihat media yang telah bekerja sama dan yang sesuai dengan target market. Media yang digunakan adalah media cetak, elektronik, online dan media sosial dengan mempertimbangkan one-way dan two-ways communication. Dalam sosialisasi 
program subsidi listrik tepat sasaran ini, public relations Distribusi Jawa Barat berperan sebagai yang menjalankan instruksi strategi komunikasi dari PLN Pusat.

\section{DAFTAR PUSTAKA}

Abidin, Yusuf Zainal. (2015). Manajemen Komunikasi: Filosofi, Konsep, dan Aplikasi. Bandung: Pustaka Setia

Cangara, Hafied. (2014). Pengantar Ilmu Кoтиnikasi. Jakarta: PT Rajagrafindo Persada

Cangara, Hafied. (2013). Perencanaan \& Strategi Komunikasi. Jakarta: PT Rajagrafindo Persada

Fajar, Mahraeni. (2009). Ilmu Komunikasi Teori \& Praktik Edisi Pertama. Yogyakarta: Graha Ilmu

Nova, Firsan. (2011). Crisis Public Relations: Bagaimana PR Menangani Krisis Perusahaan. Jakarta: Raja Grafindo Persada
Nurjaman, Kadar \& Umam, Khaerul. (2012). Komunikasi \& Public Relation. Bandung: CV Pustaka Setia

Pujileksono, Sugeng. (2015). Metode Penelitian Komunikasi Kualitatif. Malang: Kelompok Intrans Publishing

Tatang S. (2016). Dinamika Komunikasi. Bandung: CV Pustaka Setia

Suryanto. (2015). Pengantar Ilmu Komunikasi. Bandung: CV Pustaka Setia jdih.esdm. go.id

http://databoks.katadata.co.id/ datapublish/2017/01/03/subsidipelanggan-listrik-di-jabar-palingbanyak-dicabut (diakses pada tanggal 12 September 2017, pukul 23.34) 